\title{
FISH-Flow Cytometry: A High-Throughput Molecular Ecological Analysis of Intestinal Microbiota
}

\author{
Achmad DINOTO, Satoru FUKIYA, and Atsushi YOKOTA* \\ Laboratory of Microbial Physiology, Research Faculty of Agriculture, \\ Hokkaido University, Kita-9 Nishi-9, Kita-ku, Sapporo, Hokkaido 060-8589, Japan
}

\begin{abstract}
Until recently, ecological analysis of human intestinal microbiota had been conducted with culture-dependent methods. However, the majority of our intestinal bacteria remain not-yet cultured. Many culture-independent, molecular ecological methods have been developed to investigate real compositions of microbiota in the last decade. Among them, fluorescence in situ hybridization (FISH) is one of the most widely used methods, though it is time-consuming and requires laborious counting work of the detected bacteria. Development of FISH coupled with flow cytometry (FISH-FCM) has circumvented this problem. Since the development of FISH-FCM, it has been used in several fields of microbiology such as environmental microbiology and clinical microbiology. It is now being applied to more complex biological samples, such as feces. These days, intestinal microbiota analyses with FISH-FCM are being conducted not only at group or genus level, but also at the species level. Recently, we have succeeded in the development of a FISH-FCM method that is applicable to fecal samples containing high amounts of autofluorescent particles. Further development of specific probes for the bacteria of interest will contribute to the illustration of the real picture of our intestinal microbiota.
\end{abstract}

Key words : fluorescence in situ hybridization (FISH); flow cytometry (FCM); $16 \mathrm{~S}$ rRNA; intestinal microbiota; molecular ecology

\section{Introduction}

The vast community of microorganisms that colonize the human gastrointestinal tract may have important roles in the immune function, nutrient processing and a broad range of other host activities. ${ }^{12)}$ These intestinal microorganisms are estimated to be as many as 100 trillion cells, or

\footnotetext{
* To whom correspondence should be addressed.

Laboratory of Microbial Physiology, Research Faculty of Agriculture, Hokkaido University

Kita-9 Nishi-9, Kita-ku, Sapporo, Hokkaido 060-8589, Japan

Tel : $+81-11-706-2501$

Fax : $+81-11-706-4961$

E-mail : yokota@chem.agr.hokudai.ac.jp
}

about 10 times greater than the total number of our somatic and germ cells. ${ }^{3)}$ It has been estimated that human intestinal microbiota consists of about 400 to 500 species.) However, recent metagenomic analysis of human gut microbiota estimated that more than 1,000 bacterial species inhabit our gut.") Although studies on intestinal microbiota have been conducted for over one hundred years, ${ }^{6}$ the composition of microbiota in the human intestine is not yet clearly understood. Culture-dependent methods that have been used in most previous studies provide limited information on microbial communities in our intestinal ecosystem. Along with the progress of molecular biology, culture-independent methods for the analysis of the intestinal microbiota have been developed, 
which enable much more accurate analysis of the complex ecosystem than that conducted by culturedependent methods. Among them, fluorescence in situ hybridization (FISH) is considered the most accurate method for monitoring bacterial populations in fecal samples. In this review, we will discuss the current status of the application of the FISH method to the analysis of the bacterial population in human fecal samples.

\section{Culture-dependent methods}

It has been reported that the majority of microbiota in the human intestine have not yet been cultured on available non-selective media. Comparisons of total cell numbers of bacteria in feces obtained from the culture method and microscopic counts showed about 80\% (based on DAPI staining) or $70 \%$ (based on FISH analysis using probe Eub338 for total eubacteria) of observable bacteria failed to grow on non-selective media. ${ }^{7.8)}$ This may reflect unfulfilled requirements of certain bacteria on specific nutrients and/or environmental conditions to grow optimally in those media. In relation to preferable nutrients, re- cently, it has been reported that fecal bifidobacteria showed different growth responses on a Bifidobacterium-selective medium. Bifidobacterium adolescentis failed to grow on Bifidobacterium medium, whilst $B$. longum grew well on this selective medium. ${ }^{9}$ ' Those evidence demonstrate the unclearness of knowledge on intestinal microbiota based on culture-dependent methods.

\section{Fluorescence in situ hybridization}

To circumvent the problem of cultivability in intestinal microbiology, culture-independent methods have been developed in the last decade based on the progress of molecular biological techniques. ${ }^{10)}$ These methods have advantages and disadvantages in practical application, and therefore have to be selected depending on the purpose of the analysis (Table 1). Among them, quantitative real-time PCR (qRT-PCR) and FISH are widely used for quantification of microbial communities in the human intestine.

The qRT-PCR is based on the quantitative monitoring of amplification of specific 16S rDNA molecules of target bacteria. Its advantage is

Table 1. A summary of applications and features of molecular ecological methods used in intestinal microbiology

\begin{tabular}{|c|c|c|}
\hline Method & Application & Features \\
\hline Culturing & Enumeration and isolation & $\begin{array}{l}\text { Not representative because of not-yet cultured bacteria; } \\
\text { time-consuming and laborious }\end{array}$ \\
\hline $\begin{array}{l}16 \mathrm{~S} \text { rDNA library } \& \\
\text { sequencing }\end{array}$ & $\begin{array}{l}\text { Phylogenetic analysis and taxonomic } \\
\text { identification }\end{array}$ & $\begin{array}{l}\text { Exact phylogenetic information of unknown bacteria will be } \\
\text { acquired; requires cloning and sequencing of many samples }\end{array}$ \\
\hline DGGE/TGGE & Monitoring of population transition & $\begin{array}{l}\text { Rapid comparison of population transition is possible in many } \\
\text { samples; bacterial identification requires cloning and } \\
\text { sequencing of objective fragments }\end{array}$ \\
\hline T-RFLP & Monitoring of population transition & $\begin{array}{l}\text { High sensitivity; high-throughput with fluorescent DNA } \\
\text { analyzer; practically restricted for major population analysis }\end{array}$ \\
\hline FISH & Detection and direct enumeration & $\begin{array}{l}\text { Absolute number of target bacteria will be acquired; } \\
\text { high-throughput analysis is possible with image analysis or } \\
\text { flow cytometry; manual counting is laborious }\end{array}$ \\
\hline Quantitative real-time PCR & Detection and estimation of proportion & $\begin{array}{l}\text { Very high sensitivity; biases against target amplification in } \\
\text { PCR might affect the estimation of bacterial proportion }\end{array}$ \\
\hline Dot-blot hybridization & $\begin{array}{l}\text { Detection, estimation of proportion } \\
\text { and activity }\end{array}$ & $\begin{array}{l}\text { Bacterial activity will be estimated by the ratio of } \\
\text { rRNA/rDNA; analysis of many samples is laborious }\end{array}$ \\
\hline Diversity Microarray & Detection and estimation of proportion & $\begin{array}{l}\text { Detection of many bacteria is possible at a time; accuracy } \\
\text { of quantification should be improved; under-development }\end{array}$ \\
\hline
\end{tabular}


high sensitivity. The detection limit of bacteria in human fecal sample by qRT-PCR is approximately $10^{5}-10^{6}$ bacteria/g feces when genomic DNA is used as a template. It should be noted that the qRT-PCR can only estimate the relative abundance of target bacteria and biases might occur in amplification of target molecules. FISH has an advantage in direct detection and enumeration of bacteria. It can detect bacteria based on the hybridization between the sequence of $16 \mathrm{~S} r \mathrm{RNA}$ molecules in bacterial cells and the 16S rRNAtargeted oligonucleotide probe labeled with fluorochrome. The target bacterial cells can be detected under an epifluorescence microscope and enumerated for the proportion of those cells against total bacterial cells stained with suitable DNA stains such as DAPI (4',6-diamidino-2-phenylindole) 11) Enumeration of bacteria with FISH is limited for major groups of intestinal microbiota because of its sensitivity. It has been reported that over $10^{8}$ bacteria/g feces are needed for reliable enumeration in FISH analysis. ${ }^{12)}$ Nevertheless, several sets of 16S rRNA-targeted oligonucleotide probes have been constructed and applied to the monitoring of intestinal microbiota both at the genus/group and at the species level in humans ${ }^{7.12-14)}$ and in animals. ${ }^{15)}$

FISH analysis for determining the proportion of certain bacteria in a complex sample is conducted by visualization of the target cells using an epifluorescence microscope (FISH-microscopy) followed by counting of the bacterial cells manually. Although FISH is a satisfactory method for reliable quantification of bacteria, manual counting of bacteria in FISH-microscopy is laborious and time-consuming work. Nowadays, two methods have been developed to circumvent this bottleneck. One is the automated enumeration of bacteria in FISH-microscopy using high-resolution image analysis. ${ }^{16)}$ This method has the advantage of obtaining absolute numbers of total and target bacteria. However, its requirement of special computer software has prevented its widespread adoption. The other method is FISH coupled with flow cytometry (FISH-FCM). The latter seems to be more popular than the former because of the availability of FCM and its high-throughput property

\section{FISH-FCM}

\section{4-1. Principle of FISH-FCM}

FCM is a high-throughput method that is able to perform quantitative analysis of a large number of cells with single cell resolution. Thousands of cells can be analyzed from one sample within several seconds. FCM can analyze specific physical and chemical characteristics of cells or particles in a liquid stream through laser beam(s). In general FISH-FCM analysis, cells are fixed and hybridized with specific fluorescent probes. The cells are loaded to the center of a sheath flow, which surrounds a sample flow in the flow cell (Fig. 1). Based on the slight difference in the pressure between the sample and sheath flow, the sample flow is directed to the hydrodynamic focusing that forces the cells to flow one by one. The cells, thus separated, are transported to the region for optical measurements. The cells scatter light and generate spectral bands of light and emit fluores-

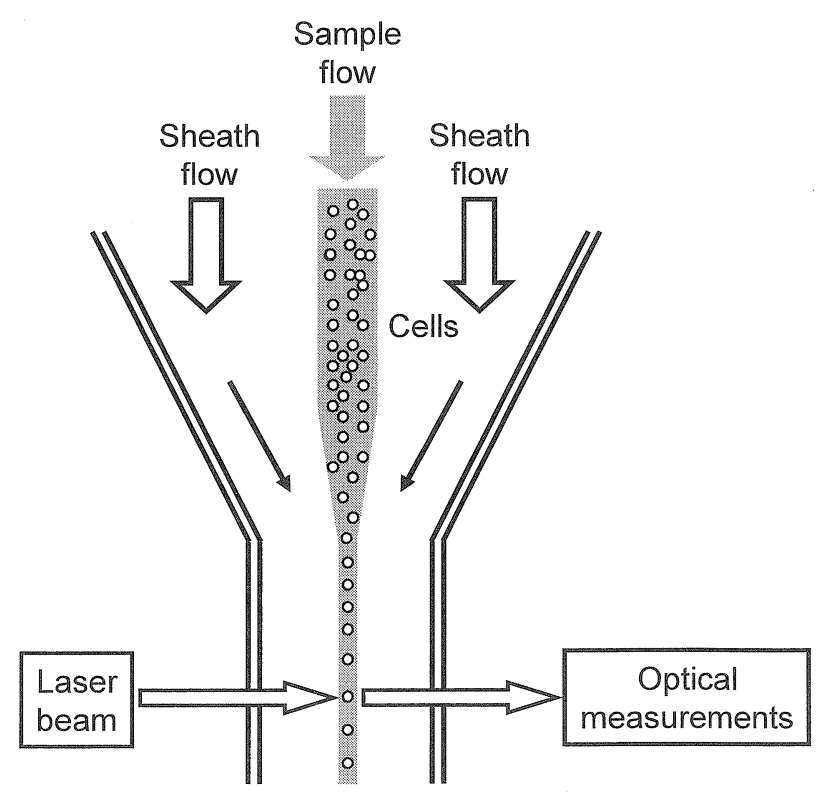

Fig. 1. Fundamental structure of a flow cell in flow cytometry. Sheath fluids flow from the large area to the very narrow area. Cells in the sample flow are injected into the center of the sheath flow, and are forced to align in single file because of the hydrodynamic focusing. Then the cells flow across the laser beam and optical information such as cell size, intracellular contents and fluorescence is collected. 
cence during sensing and measuring. Information about the cells including cell size, their contents and fluorescence can be analyzed simultaneously. In order to reduce the background noise and to exclude the non-targeted cells, both setting of an electronic threshold and gating of the targeted cells are performed in the analysis. ${ }^{17,18)}$

\section{4-2. Application of FISH-FCM in intestinal micro- biology}

Considering the advantages of FISH-FCM as a high-throughput method, this technique has been successfully applied in clinical, environmental and food microbiology. For example, detection, enumeration and population analyses have been conducted in specific bacteria in soil, ${ }^{19)}$ bacterial population in marine water, ${ }^{20)}$ contamination of Staphylococcus aureus in blood culture ${ }^{211}$ and lactic acid bacteria in dairy starter cultures. ${ }^{22}$ The successful application of FISH-FCM has been reported in the microbiota analysis of human feces for the detection of several groups of bacteria, including Bacteroides-Prevotella, Bifidobacterium, Atopobium cluster, Clostridium coccoidesEubacterium rectale cluster, Clostridium leptum subgroup and so forth. Generally, fecal samples are hybridized with a mixture of oligonucleotide probe labeled with Cy5 (indodicarbocyanine) and another probe labeled with FITC (fluorescein isothiocyanate). This method is called Cy5/FITC double-staining FISH-FCM. In the double-staining FISH-FCM method, the target bacteria are calculated as a proportion of total bacteria based on the hybridization of the Eub338 probe that can detect all of the eubacteria. ${ }^{11)}$ This method was used for identification and enumeration of uncultured Ruminococcus obeum-like bacteria in human feces. ${ }^{23)}$ The reliability of this method has been confirmed by comparing the results with those obtained by FISH-microscopy analysis ${ }^{237}$ or ribosomal RNA dot-blot hybridization analysis. ${ }^{24)}$ These comparisons resulted in similar tendencies. Recently, the Cy5/FITC double-staining FISH-FCM method has been applied to the monitoring of the composition of intestinal microbiota in healthy people who had received a normal diet in Europe ${ }^{25-27)}$ as well as people who had received probiotics administration $^{28)}$ or infants who had been administered prebiotics-containing milk formula after treatment with antibiotics. ${ }^{29)}$ Bacterial communities involved in the conversion of lignan to estrogenlike compounds in human intestine have also been investigated. ${ }^{30}$ Inter-individual variation in the composition of human fecal microbiota has also been detected. $^{31)}$ Application of FISH-FCM is not restricted to the groups/genus level; the species level detection has been successfully conducted in Bacteroides and Clostridium. ${ }^{26,27,32,33)}$ DNA-staining fluorescent dye (SYTOX ${ }^{\circledR}$ Orange) has recently been applied as an alternative method for detecting total bacteria in FISH-FCM analysis. ${ }^{34)}$ Current reports on the application of FISH-FCM to the analysis of human intestinal microbiota (fecal samples) are summarized in Table 2.

\section{4-3. FISH-FCM with Cy5-single staining method}

Although double-staining FISH-FCM analysis with Cy5 and FITC has been applied in several works for monitoring bacterial population in fecal samples, our research has revealed that this method is not directly applicable to fecal samples collected from people living in Japan. ${ }^{35)}$ It was found that a high autofluorescence signal detected from the samples under the FITC channel in double-staining FISH-FCM analysis severely interfered with the accurate measurements of the target bacterial population. However, this autofluorescence was apparently not detected under the Cy5 channel. Therefore, Cy5 was judged to be suitable as a labeling dye for the oligonucleotide probe used in the analysis of these fecal samples. It seems that the autofluorescent particles could be residues of plant fibers, because we frequently observed fiber-shaped, highly autofluorescent particles under an epifluorescence microscope, when the detection filter for FITC was selected. Autofluorescence in FISH-FCM analysis under the FITC detection channel has also been reported in a fecal sample collected in Europe, though at a relatively low level. ${ }^{23)}$ It might reflect the difference of diets between Europe and Japan, since relatively higher amounts of plant fibers are contained in the Japanese diet.

Based on these findings, we have tested the 
feasibility of Cy5 single-staining FISH-FCM for monitoring bifidobacterial populations in fecal samples containing relatively high amounts of autofluorescent particles (fecal samples collected in Japan) using BD FACSCanto ${ }^{\text {TM }}$ (BD Bioscience, San Jose, CA). The proportion of the cells hybridized with the probe for bifidobacteria (Bif164 m) was calculated against the total number of bacterial cells successfully hybridized with the probe for total bacteria (Eub338) after subtracting the background fluorescence of the negative probe (Non338). The representative results of the measurements are shown in Fig. 2; the background signal of the negative probe was observed to be very low. ${ }^{35)}$ The results of calculated proportions of bifidobacteria in many fecal samples by this method were very similar to those obtained by FISH manual counting analysis. For example, proportions of Bifidobacterium genus in two fecal samples were measured as $16.7 \%$ and $6.7 \%$ by FISHFCM analysis and $19.9 \%$ and $6.9 \%$ by FISH manual counting analysis, respectively. ${ }^{35)}$ Therefore, we have concluded that the Cy5 single-staining FISHFCM has been successfully established as a feasible method for monitoring bacterial populations in fecal samples even with high numbers of autofluorescent particles. Furthermore, we have confirmed that this method is applicable to the monitoring of bifidobacterial populations, even at the species level, which allowed us to monitor population dynamics of such bifidobacterial species as $B$. adolescentis, B. longum, B. catenulatum group, $B$. breve, $B$. bifidum, $B$. dentium and $B$. angulatum in human feces during prebiotic administration. ${ }^{35}$

\section{Conclusion}

The double-staining FISH-FCM method with Cy5 and FITC has been revealed as a promising molecular ecological tool for high-throughput analysis of microbiota in fecal samples. In our study, however, the feasibility of this method severely depends on the amounts of autofluorescent particles in a given fecal sample. The establishment of the Cy5 single-staining FISH-FCM method undoubtedly extends the applicability of FISH-FCM to a wide variety of fecal samples, even those having high autofluorescence. Along with the further development of the appropriate species-specific probes for the bacteria of interest, FISH-FCM analysis will become more popular and contribute to a deeper understanding of intestinal microbiota.

Table 2. Application of FISH-FCM for monitoring human intestinal bacteria

\begin{tabular}{|c|c|c|c|}
\hline Target bacteria & No. of detected Group/Species & Fluorescent dye* & Reference \\
\hline \multicolumn{4}{|l|}{ Group/genus level: } \\
\hline Ruminococcus obeum-like bacterium & 1 & Cy5, FITC & Zoetendal, 2002 ${ }^{23)}$ \\
\hline Group of fecal bacteria & 6 & Cy5, FITC & Rigottier-Goiis, $2003^{24)}$ \\
\hline Group of fecal bacteria & 4 & Cy5, FITC & Rochet, $2004^{31)}$ \\
\hline Group of fecal bacteria & 4 & Cy5, SYTOX ${ }^{\circledR}$ Orange & Vaahtovuo, $2005^{34)}$ \\
\hline Group of fecal bacteria & 7 & Cy5, FITC & Garrido, 2005 ${ }^{28)}$ \\
\hline Group of fecal bacteria & 1 & Cy5, FITC & Saunier, 2005 \\
\hline Group of fecal bacteria & 6 & Cy5, FITC & Clavel, $2005^{30)}$ \\
\hline Group of fecal bacteria & 6 & Cy5, FITC & Brunser, 2006 $6^{29)}$ \\
\hline \multicolumn{4}{|l|}{ Species level: } \\
\hline Bacteroides & $1 / 5$ & Cy5, FITC & Rigottier-Goiis, 2003 ${ }^{32)}$ \\
\hline Group, Clostridium and Bacteroides & $12 / 6$ & Cy5, FITC & Lay, $2005^{26)}$ \\
\hline Group, Clostridium and Bacteroides & $12 / 6$ & Cy5, FITC & Lay, 2005 \\
\hline Group, Bacteroides & $12 / 2$ & Cy5, FITC & Mueller, 2006 $6^{27)}$ \\
\hline Bifidobacterium & $1 / 7$ & $\mathrm{Cy} 5$ & Dinoto, $2006^{35)}$ \\
\hline
\end{tabular}

* Cy5, indodicarbocyanine; FITC, fluorescein isothiocyanate. 
(A) Total Bacteria (Eub338 probe)

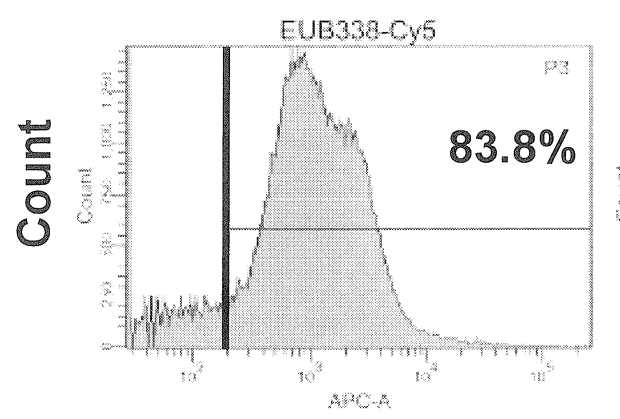

(B) Bifidobacteria (Bif164m probe)

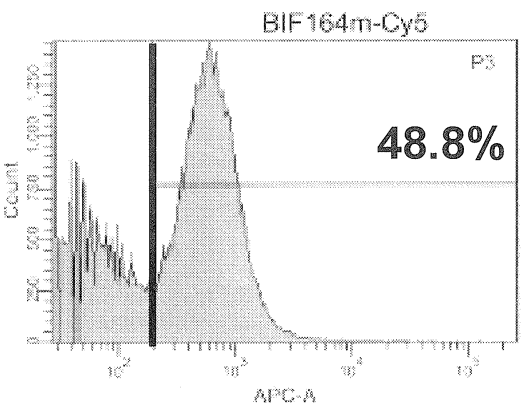

(C) Negative Control (Non338 probe)

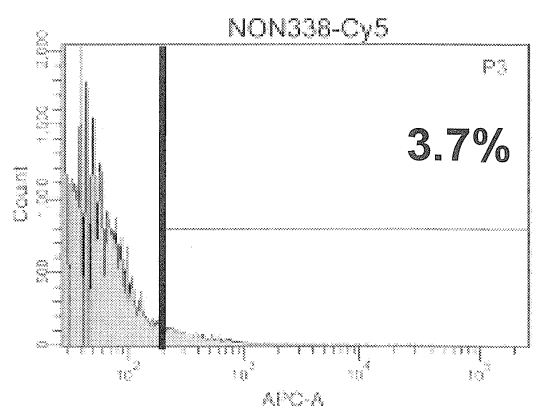

\section{Cy5 fluorescent intensity}

Fig. 2. Three histograms obtained from FISH-FCM analysis of fecal samples in one representative subject. Histograms are ordered horizontally as samples hybridized with (A) total bacterial probe/Eub338-Cy5, (B) bifidobacteria-specific probe/Bif164 m-Cy5, or (C) negative probe/Non 338-Cy5. Threshold for detection of Cy5 fluorescence is indicated by a black bold line parallel to the vertical axis. Percentages of the Cy5positive cell counts to the total counts $\left(10^{6}\right.$ particles) are indicated in each histogram. The count of background fluorescence $(3.7 \%$ in C) was subtracted from those of total bacteria $(83.8 \%$ in A) and bifidobacteria $(48.8 \%$ in B) and then the proportion of bifidobacteria in total bacteria was calculated, $56.3 \%$ in this sample $\{(48.8-3.7 / 83.8-3.7) \times 100\}$.

\section{Acknowledgments}

Our work indicated in this review was supported in part by the Special Coordination Funds

\section{REFERENCES}

1) Crittenden, R.G.: Prebiotics, p.141-156, Probiotics: A Critical Review, ed. by Tannock, G.W., Horizon Scientific Press, Wymondham, England (1999).

2) Hooper, L.V., and Gordon, J.I.: Commensal hostbacterial relationships in the gut, Science, 292, 11151118 (2001).

3) Savage, D.C.: Microbial ecology of the gastrointestinal tract, Ann. Rev. Microbiol., 31, 107-133 (1977).

4) Moore, W.E.C., and Holdeman, L.V.: Human fecal flora: the normal flora of 20 Japanese-Hawaiians, Appl. Microbiol., 27, 961-979 (1974).

5) Gill, S.R., Pop, M., DeBoy, R.T., Eckburg, P.B., Turnbaugh, P.J., Samuel, B.S., Gordon, J.I., Relman, D.A., Fraser-Liggett, C.M., and Nelson, K.E.: Metagenomic analysis of the human distal gut microbiome, Science, 312, 1355-1359 (2006).

6) Tissier, H.: La reaction chromophile d'Escherich et le Bacterium coli, C. R. Soc. Biol., 51, 943-945 (1899).

7) Langendijk, P.S., Schut, F., Jansen, G.J., Raangs, G.C., Kamphuis, G.R., Wilkinson, M.H.F., and Welling, G.W.: Quantitative fluorescence in situ hybridization of Bifidobacterium spp. with genus-specific $16 \mathrm{~S}$ rRNA-targeted probes and its application in fecal samples, Appl. Environ. Microbiol., 61, 3069-3075 (1995).

8) Suau, A., Bonnet, R., Sutren, M., Godon, J.J., Gibson, G.R., Collins, M.D., and Dorẻ, J.: Direct analysis of genes encoding 16S rRNA from complex for Promoting Science and Technology, commissioned by the Ministry of Education, Culture, Sports, Science and Technology of Japan.

communities reveals many novel molecular species within the human gut, Appl. Environ. Microbiol., 65, 4799-4807 (1999).

9) Apajalahti, J.H.A., Kettunen, A., Nurminen, P.H., Jatila, H., and Holben, W.E.: Selective plating underestimates abundance and shows differential recovery of bifidobacterial species from human feces, Appl. Environ. Microbiol., 69, 5731-5735 (2003).

10) Zoetendal, E.G., Collier, C.T., Koike, S., Mackie, R.I., and Gaskins, H.R.: Molecular ecological analysis of the gastrointestinal microbiota: a review, $J$. Nutr., 134, 465-472 (2004).

11) Amann, R.I., Binder, B.J., Olson, R.J., Chisholm, S.W., Devereux, R., and Stahl, D.A.: Combination of 16S rRNA-targeted oligonucleotide probes with flow cytometry for analyzing mixed microbial populations, Appl. Environ. Microbiol., 56, 1919-1925 (1990).

12) Franks, A.H., Harmsen, H.J.M., Raangs, G.C., Jansen, G.J., Schut, F., and Welling, G.W.: Variations of bacterial populations in human feces measured by fluorescent in situ hybridization with groupspecific 16S rRNA-targeted oligonucleotide probes, Appl. Environ. Microbiol., 64, 3336-3345 (1998).

13) Harmsen, H.J.M., Wildeboer-Veloo, A.C.M., Grijpstra, J., Knol, J., Degener, J.E., and Welling, G.W.: Development of 16S rRNA-based probes for the Coriobacterium group and the Atopobium cluster and their application for enumeration of Coriobacteriaceae in human feces from volunteers of different age groups, Appl. Environ. Microbiol., 66, 
4523-4527 (2000).

14) Suau, A., Rochet, V., Sghir, A., Gramet, G., Brewaeys, S., Sutren, M., Rigottier-Gois, L., and Dore, J.: Fusobacterium prausnitzii and related species represent a dominant group within the human fecal flora, System. Appl. Microbiol., 24, 139-145 (2001).

15) Dinoto, A., Suksomcheep, A., Ishizuka, S., Kimura, H., Hanada, S., Kamagata, Y., Asano, K., Tomita, F., and Yokota, A.: Modulation of rat cecal microbiota by administration of raffinose and encapsulated Bifidobacterium breve, Appl. Environ. Microbiol., 72, 784-792 (2006).

16) Thiel, R., and Blaut, M.: An improved method for the automated enumeration of fluorescently labelled bacteria in human faeces, J. Microbiol. Methods, 61, 369-379 (2005)

17) Robinson, J.P.: Flow cytometry, p.630-640, Encyclopedia of biomaterials and biomedical engineering, ed. by Wnek, G.E., and Bowlin, G.L., Marcel Dekker, New York (2004).

18) Davey, H.M., and Kell, D.B.: Flow cytometry and cell sorting of heterogeneous microbial populations: the importance of single-cell analyses, Microbiol. Rev., 60, 641-696 (1996).

19) Thomas, J.C., Desrosiers, M., St-Pierre, Y., Lirette, P., Bisaillon, J.G., Beaudet, R., and Villemur, R.: Quantitative flow cytometric detection of specific microorganisms in soil samples using rRNA targeted fluorescent probes and ethidium bromide, Cytometry, 27, 224-232 (1997)

20) Fuchs, B.M., Zubkov, M.V., Sahm, K., Burkill, P.H., and Amann, R.: Changes in community composition during dilution cultures of marine bacterioplankton as assessed by flow cytometric and molecular biological techniques, Environ. Microbiol., 2, 191-201 (2000).

21) Hartmann, H., Stender, H., Schäfer, A., Autenrieth, I.B., and Kempf, V.A.J: Rapid identification of Staphylococcus aureus in blood cultures by a combination of fluorescence in situ hybridization using peptide nucleic acid probes and flow cytometry, J. Clin. Microbiol., 43, 4855-4857 (2005).

22) Friedrich, U., and Lenke, J.: Improved enumeration of lactic acid bacteria in mesophilic dairy starter cultures by using multiplex quantitative real-time PCR and flow cytometry-fluorescence in situ hybridization, Appl. Environ. Microbiol., 72, 4163-4171 (2006).

23) Zoetendal, E.G., Ben-Amor, K., Harmsen, H.J.M., Schut, F., Akkermans, A.D.L., and de Vos, W.M.: Quantification of uncultured Ruminococcus obeumlike bacteria in human fecal samples by fluorescent in situ hybridization and flow cytometry using $16 \mathrm{~S}$ rRNA-targeted probes, Appl. Environ. Microbiol., 68, 4225-4232 (2002)

24) Rigottier-Gois, L., Le Bourhis, A.G., Gramet, G., Rochet, V., and Dorẻ, J.: Fluorescent hybridisation combined with flow cytometry and hybridisation of total RNA to analyse the composition of microbial communities in human faeces using 16S rRNA probes, FEMS Microbiol. Ecol., 43, 237-245 (2003).

25) Saunier, K., Rougẻ, C., Lay, C., Rigottier-Gois, L., and Dorẻ, J.: Enumeration of bacteria from the Clostridium leptum subgroup in human faecal microbiota using Clep1156 16S rRNA probe in combination with helper and competitor oligonucleotides, System. Appl. Microbiol., 28, 454-464 (2005).

26) Lay, C., Rigottier-Gois, L., Holmstrøm, K., Rajilic, M., Vaughan, E.E., de Vos, W.M., Collins, M.D., Thiel, R., Namsolleck, P., Blaut, M., and Dorè, J.: Colonic microbiota signatures across five Northern European countries, Appl. Environ. Microbiol., 71, 4153-4155 (2005).

27) Mueller, S., Saunier, K., Hanisch, C., Norin, E., Alm, L., Midtvedt, T., Cresci, A., Silvi, S. Orpianesi, C., Verdenelli, M.C., Clavel, T., Koebnick, C., Zunft, H.J.F., Dorẻ, J., and Blaut, M.: Differences in fecal microbiota in different European study populations in relation to age, gender, and country: a cross-sectional study, Appl. Environ. Microbiol., 72, 1027-1033 (2006).

28) Garrido, D., Suau, A., Pochart, P., Cruchet, S., and Gotteland, M.: Modulation of the fecal microbiota by the intake of a Lactobacillus johnsonii La1-containing product in human volunteers, FEMS Microbiol. Lett., 248, 249-256 (2005).

29) Brunser, O., Gotteland, M., Cruchet, S., Figueroa, G., Garrido, D., and Steenhout, P.: Effect of a milk formula with prebiotics on the intestinal microbiota of infants after an antibiotic treatment, Pediatr. Res., 59, 451-456 (2006).

30) Clavel, T., Henderson, G., Alpert, C.A., Philippe, C., Rigottier-Gois, L., Dorè, J., and Blaut, M.: Intestinal bacterial communities that produce active estrogen-like compounds enterodiol and enterolactone in humans, Appl. Environ. Microbiol., 71, 6077-6085 (2005).

31) Rochet, V., Rigottier-Gois, L., Rabot, S., and Dorẻ, J.: Validation of fluorescent in situ hybridization combined with flow cytometry for assessing interindividual variation in the composition of human fecal microflora during long-term storage of samples, J. Microbiol. Methods, 59, 263-270 (2004).

32) Rigottier-Gois, L., Rochet, V., Garrec, N., Suau, A., and Dorẻ, J.: Enumeration of Bacteroides species in human faeces by fluorescent in situ hybridisation combined with flow cytometry using 16S rRNA probes, System. Appl. Microbiol., 26, 110118 (2003)

33) Lay, C., Sutren, M., Rochet, V., Saunier, K., Dorẻ, J., and Rigottier-Gois, L.: Design and validation of 16S rRNA probes to enumerate members of the Clostridium leptum subgroup in human faecal microbiota, Environ. Microbiol., 7, 933-946 (2005).

34) Vaahtovuo, J., Korkeamäki, M., Munukka, E., Viljanen, M.K., and Toivanen, P.: Quantification of bacteria in human feces using 16S rRNAhybridization, DNA-staining and flow cytometry, $J$. Microbiol. Methods, 63, 276-286 (2005).

35) Dinoto, A., Marques, T.M., Sakamoto, K., Fukiya, S., Watanabe, J., Ito, S., and Yokota, A.: Population dynamics of Bifidobacterium species in human feces during raffinose administration monitored by FISH-flow cytometry, Appl. Environ. Microbiol., 72, 7739-7747 (2006). 


\title{
FISH-フローサイトメトリーを用いた腸内細菌叢の 迅速な分子生態学的解析
}

\author{
アハマドディノト、吹谷 智，横田 篤* \\ 北海道大学大学院農学研究院 微生物生理学研究室 \\ 厂060-8589 北海道札幌市北区北 9 条西 9 丁目
}

\begin{abstract}
これまでヒト腸内細菌叢の生態学的解析は培養法により行われてきたが、腸内細菌の大部分が未だ培養不可能なため、 正確な解析が出来ていないという懸念があった。近年、培養に依存しない種々の分子生物学的な解析手法が開発され ているが、その中であ FISH (Fluorescence in situ hybridization)法は最む汎用されている方法の一つである。しか しながら、FISH 法では菌数を手動計測する必要があるため、菌数計測を迅速化する方法の一つとして、FISH とフロー サイトメトリー (FCM)を組み合わせた FISH-FCM 法が開発された。FISH-FCM 法は環境・臨床微生物学などの分野 で既に使用されているが、冀便のような複雑なサンプルの解析にも応用され、現在では FISH-FCM 法を用いた腸内細 菌叢の解析は、細菌の群や属レベルだけでなく、種レベルについても可能となっている。最近我々は、自家蛍光物質 を多く含む筫便サンプルにも適用可能な FISH-FCM 法の開発に成功した。将来的には、標的菌種特異的なプローブの 開発に伴って、FISH-FCM 法を用いたヒ卜腸内細菌叢のより詳細な解析が可能になるすのと考えられる。
\end{abstract}

